\title{
ON THE LINGUISTICS OF DREAMS
}

\author{
Louise Pound \\ University of Nebraska
}

$\mathrm{P}^{2}$ SYCHOLOGISTs and students of literature know how vast is the literature of dreams. ${ }^{1}$ Yet, for the most part, investigators of sleep, dreams, and drowsiness have concerned themselves with the common hallucinations and perceptual phenomena that mark the transition between sleeping and waking. They have watched the pageantry of dreams, dream scenes and dream happenings; they have noted auditory and motor tendencies, and transformations and substitutions; they have probed mental states and examined trains of association; and they have tried for interpretations and explanations. Of late we have had a new school starting in Vienna that leans heavily on dream material and is obsessed with its own kind of interest in the subject. Despite, however, the existent dream literature or dream lore, I cannot find that the verbal side of dreaming has had proportionate exploration. ${ }^{2}$ It seems to me to be time that some one approach the subject from the linguistic angle only, and this paper tries that approach. It has been made independently, and it is not by a trained psychologist. But the subject has no little interest, for the layman as well as for the expert, and it deserves its share of attention.

For a few years I have collected at

$\rightarrow$ M. W. Calkins printed "Statistics of Dreams" in the American Journal of Psychology, V (1893), 311 ff. The European scholars Vold and Nillson, who worked near the turn of the century, opened the experimental era. Vold recorded his dreams during thirteen years and Nillson recorded about a thousand of his. odd times, as opportunity offered, illustrative material on the verbal phases of dream experience. Such material might be expected to be ample and easily available, but ordinarily it is pretty difficult for the normal person to recapture the words, expressions, and sentences lingering in the twilight zone between sleeping and waking. Dream language slips away as rapidly as dream pageantry, and it is not often that one dreams in intelligible language form. Expression in words is subordinate to emotional and visual experience. Yet, especially if they are watched for and fixed in the mind at once on awakening, words, fragments, sentences, sometimes longer passages may be recovered and recorded.

The material assembled by me from various sources falls conveniently into these subdivisions: (I) Dream Neologisms, (II) Dream Sayings and Bits of Dialogue and Writing, (III) Dream Verse, (IV) Fantastic Fragments or Irrelevances, (V) Hypnopompic Language.

The instances I present are authentic, for I relied solely on trustworthy contributors. It should be added that all were of the lettered class, mainly educationists, scholars, fiction writers, and verse writers. I think it probable that dreaming in word form is rarer among the unlettered.

2. A bilingual dream, as well as other interesting dream sayings, is cited in H. B. Alexander's "The Subconscious in the Light of Dream Imagery and Imaginative Expression," Proceedings of the American Society for Psy. chical Research, III (1909), 612-34. 


\section{Dream Neologisms}

These are of especial interest to linguistic students. Sometimes those who dream strange words can supply clues to their creation. At other times a word is recovered nearly in isolation; the situation in which it was evolved has faded. Its coiner cannot account for it or supply its meaning. In general dream neologisms, so far as I can learn, have not had the attention of students of language. They deserve illustration, and a list of all those I have collected follows. Most of the coinages, it will be noted, are nouns, with a few adjectives and verbs to be taken into account. Other classes of dream language will be illustrated less fully.

1. We seemed in my dream to be describing a person whom one in a group called an akromaniac. Another said, "I call him an akmaniac." A third said, "Well, I call him just a plain maniac."

2. In my dream a clown is fatally hurt and before dying he gives his idea of a real theater, exclaiming, "Let there be a Ko-Kothurnus for every man's son, and near the stage a sharp Promethean rock where one may tell his heart."

Perhaps Ko-Kothurnus is an echo of cothurnus, a high boot or buskin worn by the tragic actors of antiquity. The word was unintelligible to the dreamer, who is a teacher in a secondary school.

3. I dreamed one night of going to Canada and there finding under the trees enormous tables spread with food. When I asked the occasion for the celebration, some one said, "Why, don't you know? It's a Knode." Pronunciation $K n o-d a, k$ sounded. Meaning unknown to the dreamer.

4. As a bus-like vehicle passed out of sight I found myself saying, "There goes the old hervey down the street." I believe that the words herdic (a horse-drawn vehicle with which I was familiar for a short time in my childhood) and conveyance were in my mind.

5. Thinking of a passport visa I found myself saying, as I awoke, the word Makotin (accent on the second syllable, the $o$ as in hope).
The word was unintelligible to the dreamer.

6. As I awoke I found myself saying to a friend, "You're a regular messenaire, always messing things up."

7. I was dimly conscious that I should have been studying. A monotonous voice kept repeating, "Getcher stroubles! Getcher stroubles!" In my dream the sentence meant "Get your studies." Plainly a fusion of studies and troubles.

8. A cowboy in full regalia was showing me bright metal tools in the hope that I would buy them. "If you just had one of these ramalooms to punch holes with," he said, "you would ride swell." Possibly the term cowpuncher prompted this dream.

9. I dreamed that I was chased by dogs. I think I meant to say nauseous quadruped but the following resulted, "You get away, you nautruped!"

10. I found myself saying, "She is a very philanthrormus creature." Probably I meant philanthropic.

11. Some one said to me in a dream, "Are you so dummery as that?" The adjective meant stupid and is plainly to be associated with dumb.

12. At a gay party one couple seemed a bit queer. Some one suggested that they could go to a freak show as Mr. Shirt and Wirt. Obviously wife was the word meant.

13. I dreamed that I always keep an ArcoBromley cat at Waverley Place. Variant: ArcoBailly. This seemed to be the name of a high breed of cats. Literally high, for the cat I saw in my dream seemed to dart about the top of a high dinly lighted wall, and though it was a large cat it seemed to look somewhat like a brown squirrel. Arc-light may have had something to do with the name. "Waverley Place" I cannot explain.

14. A woman was rushing frantically about a nursery exclaiming "Dorianna, where's Dorianna?" I think this name was a dream-coinage, I doubt whether I ever heard or read it.

15. "See that? That is where misers mise their treasure." This was the only instance of a back formation that was contributed.

16. In my dream I was attending a play. All that $I$ recall was my exclamation on seeing a purple and gold theatrical set, "O what a beautiful zmik!"'

17. See also huckalooed, III, 6. 
In the following instances familiar words were used in an unfamiliar way:

18. I dreamed that my son and I were surrounded by wolves. After beating them off with a club I said to my son, "Why will you go wolving around that way?"

19. In my dream I was somewhere in the West. The party of which I was a member was supposed to ride horseback. But I objected to this. A big burly individual, not a cowboy, said contemptuously, "Can't you cheese it?" I turned to someone for explanation and learned that cheese it meant to ride astride.

20. I was going to make something for a domestic science exhibit. I said in my sleep, "I could bake a patte." Patte meant to me a little French cake. I do not know French.

Probably pâté was the word in the dreamer's mind.

21. My mother dreamed that she and a friend came into her home to find a strange man asleep there and she exclaimed: "He looks just like an Oher." Oher is Moravian for giant. She speaks Moravian only occasionally.

\section{Sayings and Bits of Dialogue AND WRITING}

These are often as surprising or novel or humorous, yet intelligible, as are dream neologisms. Some suggest trains of association; some are pithy and pretty logical; most are somehow vaguely telling. ${ }^{3}$ There is little sustained creation.

3. A few such sayings are entered $\rightarrow$ H. L. Hollingworth's "The Psychology of Drowsiness," American Journal of Psychology, XXII (1911), 99-211. Brander Mathews has some amusing dream sayings in These Many Years (1917), pp. 434-36, and Mark Twain records some interesting dream words in "My Platonic Sweetheart," Harper's Magazine, Dec., 1912.

4. Lafcadio Hearn, "Readings from a DreamBook," in Shadowings (1900), admits that he could not recapture his "readings" exactly and filled in and rearranged them in his waking moments: "By regularly taking care to write down immediately upon awakening whatever I could remember reading in the dream-book, I found myself able to reproduce portions of the text. But the order in which I now present these fragments is not at all the order in which I recovered them. If they seem to have any
In literary biography instances are recorded of dreamers of unusually vivid imagination and retentive memory who can hold long speeches in the mind, or long descriptive passages; but I have not found such persons among my contributors. ${ }^{4}$

1. Many testify to hearing names called out suddenly, theirs or the names of relatives, friends, or acquaintances, and sometimes names that are unfamiliar, like the "Dorianna" of I, 14 .

2. I am now twenty but in my dream thought myself a little girl. I went with my father to a hospital to see my mother. Just before leaving the hospital I heard a nurse say to my father, "You're going to have a little benefit in three weeks." Apparently benefit referred to an approaching birth.

3. I dreamed that a friend was thinking of buying a dachshund. I looked at the animal and awoke, finding myself saying, "It seems to be missing some arms and legs. You'd better refer the matter to an expert." I think I was confusing the animal with a centipede.

4. My cousin, talking in her sleep, said, "The corner of my neck hurts."

5. This was dreamed in my early youth. My older sister reproved me for some request. “Don't be a pert little monkey." I responded, "I was not pertly monkeying, I was politely requesting."

6. I was taking an oral examination preparatory to entering the Omaha Central High

interconnection, this is only because I tried to arrange them in what I imagined to be the rational sequence. Of their original place and relation I know scarcely anything."

One suspects that Coleridge when recording his dream poem Kubla Khan rearranged or filled in, in wakeful composition, in something the manner of Hearn. His first line, from Purchas, may well have been the cue for the dream imagery and Coleridge followed the cue when awake. His dream impulse may have run out, since there was nothing behind it, and the story of the interruption by the person from Porlock be apocryphal.

There is literary interest and sometimes literary quality in the trance utterances of Mrs. Verrall, as recorded in the Proceedings of the Society for Psychical Research, and also in those of Patience Worth. 
School. "Are you married?" queried the examiner? "Yes." "Who to?" "My husband."

7. In my dream Dr. Terman of Berkeley was saying to a group of students that people don't know what they say. He proceeded to remark that he was going to ask each of them for a sentence and that he doubted whether they would know the meaning of the words they said. My sentence was, "The King of England is a good fellow."

8. I had been reading detective stories. I dreamed the following and managed to retain it, because of its character, long enough to get it down. It opened with the first chapter of a learned [sic] book I was writing. " $\mathrm{X}$ marks the spot where the body of Sir George Soho was found at the foot of the statue of Emanuel Swedenborg in Collum Square. The question is, "Who whisked away the corpse?" "

9. I dreamed that I had written a book, apparently on American place-names, and I was reading a long review of it. I read it paragraph after paragraph and was much provoked to come upon this sentence: "We can hardly expect a work in which the author writes Charleston as Charles Town to be taken seriously." The correct form really was Charles Town, and I had taken great pains to preserve it. My annoyance at the reviewer's unfairness was so strong that it woke me up, and hence I was able to recall the sentence. I could remember only one other phrase from the review, "The author has his ax out for Schoolcraft." This refers, I suppose, to the Amerindian scholar Henry Rowe Schoolcraft, whose accounts of travels in Missouri I have had occasion to use; but $\mathrm{I}$ have never formed an opinion one way or another about him.

Some dream sayings show cunning or suggest thought, though the thought is non-intellectual. A special type of subconscious or half-conscious "wit" may lie back of some dream utterances. Certainly many have an oracular or poetic value. That the whole range of proverbs, apothegms, spells, or "runic sayings," has a dream or trance background if it could be found, is the conjecture of one contributor, a person unusually endowed as regards imagina- tion and powers of thought and expression. The following sayings are from this dreamer.

10. I was reading a newspaper and was struck by a headline, "Says Truth is the Profile of Reality." In my dream I understood this to be a reporter's version of some speech, presumably notable. As a matter of fact, this definition of truth is as good as any $I$ have ever seen. I should stand by it with my waking wits.

11. I'm a man of decision. I always flip a coin.

12. His is a transparent nature. Yes, he has lucid intervals.

13. Freely and without prejudice books offer their counsel.

\section{Dream Verse}

The relation of dreams to poetry has long been of interest to students of either subject. Much has been written of this relation, in its various phases, in our own and in other times. ${ }^{5}$ The dream or trance songs of primitive peoples have had attention as well as the compositions of sophisticated moderns. Milton and Coleridge are familiar examples of poets who composed expanded consecutive passages in sleep and retained them well enough to write them out on awakening. My illustrations of dream verse are nearly all in single-line form. The context of the lines had faded. Most came from persons who had printed more or less verse.

1. I dreamed this line-I cannot explain it:

"Lest we too clearly see ourselves go halting by."

2. This is all that stayed of a poem I composed in my dream:

"Through your own shadow glow departed blessings."

5. See Poetry and Dreams by F. H. Prescott (1912). Also my Poetic Origins and the Ballad (1921), Chapter I, and my "Caedmon's Dream Song," Studies in Philology in Honor of Frederick Klaeber" (1929). 
3. In my dream I composed a poem ending with these words, which are all that I recall of it:

"And memory crawls up the wrinkled years." 4. The same dreamer reported also:

"On the wall the firelight twittering."

5. My sister composed in a dream a popular song having this title, which was all she remembered of it:

"Paw, let the cows pass by."

6. In a dream I was reading the St. Louis Post-Dispatch. I saw very clearly the newspaper page and on it was printed a poem entitled "The Stars." I read with a waxing glow a poem of perhaps twenty or thirty lines, until I came to the last and most thrilling line of all. "Ah," thought I in my dream, "could I write but one such line I should be a poet." When I awoke the line or verse still remained vivid. It was:

"And the Morning Star huckalooed to the Ladies."

7. The following quatrain was reported as dreamed in Philadelphia in 1893 , by a man who had seen a prizefight the day before:

"At first they fought with tooth and tongue,

But when it came to blows,

The man who had the stronger lung

Blew off the other's nose."

8. These bits of a poem lingered when I awoke. I had been reading Emily Dickinson that night.

"And we who plotted pyramids Diapers obtain."

Variants were "plotted Pyrenees" and "planned peninsulas.”

These dream lines seem to be a distorted auditory image of part of Emily Dickinson's poem:

"A furlong than a league Inflicts a pricklier painTill we, who smiled at Pyrenees, Of parishes complain."

\section{FAntastic Fragments OR IRRELEVANCES}

Linguistic material of this type is frequent in dreams, but its lack of point or its non-sequitur character makes retention of it in the mind unlikely. Sometimes single lines that have no apparent meaning are said over and over again. It is hard to see how they came to put themselves together or to stay in the memory. Some fragments have traces of sense. Others are absurd or unintelligible or irrelevant. Here are a few illustrations.

1. On awaking I found myself saying, and believing it poetry, this line: "Fellow in the food, that's what it means."

2. I repeated, "They came from afar in circles." To whom or what "they" referred I was unable to recall.

3. "I dwelt among the tree tops." I can't explain this. My relatives commented that it showed "Tarzan influence."

4. I could not recall on awakening the situation on which I found myself saying over and over these words of comment, "She is a real boy hero, pursuant upon the consequences."

5. For no accountable reason I was talking to a man from whom I wished to buy some rattlesnakes. When $I$ asked about them he said, "O, you mean Fish? They're Devils. They're dangerous!" Fish seemed a queer synonym for rattlesnake.

6. In my dream there was a knock at the door and two girls appeared. They looked like students and were carrying books. As I opened the door they asked me for food. At this I burst into violent laughter and responded, "My name is Miss Pettyjinn!" What brought this surname to my mind, or why I was so unsympathetic, I do not know.

\section{HyPNOPOMPIC LANGUAGE}

A tendency toward highfalutin language or verbal pomposity is often exhibited, at least in the dream speech of the highly educated. It probably corresponds to the illusions of vastness or grandeur that are familiar in the pageantry of dreams. For this tendency I have used the word hypnopompic, perhaps inadvisedly since this is not the sense in which the term was employed by F. W. H. Myers, who launched it. ${ }^{6}$

6. F.W.H. Myers, Human Personality (1903). 
Sleep-inducing images are hypnogogic and sleep-dispelling images are hypnopompic. As I employ the term, the emphasis is on pomp, in its present-day meaning, too, not in the sense of the Greek pompos, conductor or guide. Pretentious speech, such as the dreamer would hardly use ordinarily, formulates itself in sleep and seems to him appropriate and impressive, although, when he awakens, it may seem the opposite.

1. See "The Morning Star huckalooed to the Ladies" (III, 6).

2. See "Let there be a Ko-Kothurnus for every man's son, etc." (I, 2).

3. I was lured into forbidden palace by the Anti-Christ. As the gates closed behind me he boomed: "Dire destruction to all who come into my portals." Probably I was echoing some sixteenth-century reading matter that I had been going through.

4. I dreamed that I composed a novel. It seemed to be of the swashbuckling type and of the period of the Crusades. I had been discussing Sir Walter Scott in class. All that I remembered on awaking was the title, which I thought marvelous, "The Philandering Hick."

5. A year later I wrote another novel, again after classroom discussion of fiction. The contents escaped me altogether, but again I remembered the title, "Wastebaskets of the Mighty."

My novel writing in dreams does not mean that I have "suppressed desires" in this direction. Had I ever wished, in my waking moments, to write novels, I would have done so.

6. The young son of a friend awoke to find himself saying (he told it to his mother who was so impressed by it that she wrote it down at once): "He found peace at last in the bottom of a well."

On the whole, the dream coinages, sayings, and bits of dialogue and verse that I have cited seem to me to be mainly random fusions, chance creations suggested by words or memories or reading matter emerging from the hinterland of the sleeper's mind. A psychoanalyst examining my material might find that it symbolized something profound in his field, or perhaps something hectic. The Freudians rely amazingly on dream material. According to the popular idea of them they might deduce that my masculine contributors wished to marry chorus girls and my feminine contributors their chauffeurs. Yet it is still a question whether dream lore has much underlying significance of this type that is trustworthy.

It is natural that the linguistic material of dreams should have had less attention than other phases of dream experience. Most dreams are more imagery than wrought words or wrought phrasing. The emotional or visual experiences or the happenings of dreams loom larger than the verbal element. Dreams are a subjective, private matter, while speech and writing are external and social. Language formulates itself with awakening to the outer world. The utterances of dreams have, nevertheless, curious in terest, like other phenomena of dreams. Perhaps when such material has been brought together over long periods of time, and from many sources, it may be found to have not only unmistakable human interest but a scientific value that is not now apparent. 